\title{
The 33rd International Geographical Congress Held Successfully in Beijing, China
}

The 33rd International Geographical Congress (IGC 2016) was held in Beijing, China on August 21-25, 2016. About 5000 participants from 101 countries and regions worldwide attended the congress and related activities. The congress was hosted by International Geographical Union, organized by Geographical Society of China and Institute of Geographic Sciences and Natural Resources Research, Chinese Academy of Sciences. The theme of the 33rd IGC was "Shaping Our Harmonious Worlds". Through academic exchanges and communications on geography, the congress aimed at promoting the harmony between humankind and nature, respecting the nature and cultural difference, and leading geographers from all over the world to conduct the researches on global understanding, future earth and sustainable development in a profound way.

The Congress began with the Opening Ceremony held at the China National Convention Center (CNCC), on August 22. Yanhua Liu, Co-chair of the 33rd IGC Organizing Committee, Counselor of the State Council, China, Vladimir Kolosov, President of the International Geographical Union (IGU), Dahe Qin, Co-chair of the 33rd IGC Scientific Committee, Academician of Chinese Academy of Sciences (CAS), Wei Shu, Executive Secretary of the China Association for Science and Technology (CAST) and Jinghai Li, Vice President of the International Council for Science (ICSU), Vice President and Academician of Chinese Academy of Sciences (CAS) successively delivered speeches on the opening ceremony. Many well-known and influential scientists were also present at the congress, which included Chinese academicians Bojie Fu, Changming Liu, Du Zheng, Ying Wang, Dadao Lu, Anthony Yeh, Tandong Yao, Peng Cui, Fahu Chen, Jun Xia, and Vladimir Kotlyakov, Honorary President of the Russian Geographical Society, Nikolay Kasimov, First Vice President of the Russian Geographical Society, Jean-Robert Pitte, President of Société de Géographie France, Michael Meadows, Secretary-General of IGU, Alexander Murphy, Former President of AAG, Douglas Richardson, Executive Director of AAG, etc. The opening ceremony was chaired by Chenghu Zhou, Secretary-General of the 33rd IGC Organizing Committee, Vice President of the IGU, Academician of CAS. During the last part of the ceremony, the outstanding individuals of the 13th iGeo were awarded the gold medals.

During the congress, 9 plenary lectures were made by 10 world-famous scholars, which were Geographical Sciences and Future Earth: Research for Solutions, from Local to Global Scales given by Mark Stafford Smith (Australia), Understanding Chinese Geography: Linking Science and Society by Bojie Fu (China), Back to the Future: Reasoning the Terriatorial Way of Life by Woo-ik Yu (South Korea), Urban Dynamics and Geo-diversity: From Theory to Modeling by Denise Pumain (France), A 21st Century Agenda to Shape “Our Harmonious Worlds" Through Research on the Geographies of Health and Care by Mark W. Rosenberg (Canada), Climate Change and Its Impact by Dahe Qin (China), Geography and Future Earth: Perspectives from Africa by Michael Meadows (South Africa), Global Understanding for Global Sustainability by Benno Werlen (Germany), From Inter-state to Multiscalar Political Geographies by Virginie Mamadouh (Netherlands) and Takashi Yamazaki (Japan).

262 sessions were organized during the congress, which included 156 thematic sessions proposed by 41 IGU Commissions, 44 sessions which focused on 5 key topics: "Geographical Sciences and Future Earth", "Climate Change and Global Understanding", "Urbanization and Sus- 
tainable Development", "Environment-Health and Social Welfare" and "Geography in Different Cultures", 42 forums, symposiums, keynote lectures and special sessions, such as "Forum for Think Tank of International Scientists Union of "the Belt and Road Initiative", "Forum for Resources and Environment of Central Asia across Silk Road Economic Belt", "3rd International Conference on Mountain Environment and Development, ICMED", "Inheritance and Innovation of Geography: Young Scholar in Action" and 20 business meetings. In about 500 time slots of oral sessions, 2600 presentations were made. In parallel to oral sessions, 1200 posters were presented.

The exhibition attracted nearly 40 domestic and international publishers, companies, institutions and organizations. Many recent published achievements and products in the relevant field were presented.

According to the IGU customs, IGU General Assembly was held during the congress. In the General Assembly attended by representatives from 46 countries, the new national members, IGU Commissions, Task Forces and their chairpersons were approved. The IGU new President and new Executive Committee were elected, and host city (Dublin, Ireland) of the International Geographical Congress 2024 was decided by vote.

The Congress came to a close on the afternoon of August 25. Bojie Fu, President of Geographical Society of China presented the basic statistics and made a summary of the congress. Vladimir Kolosov, the outgoing President of IGU delivered a speech of thanks and confirmed the success of the congress. Then IGU and LOC Grant recipients were announced. IGU Commission Excellent Award 2015 was presented to Commission on Geographical Education; IGU Planet and Humanity Medal was awarded to Prof. Carl Folke, IGU Lauréats d'Honneur were presented to Prof. Ian Burton, Prof. Maria Dolores Garcias-Ramon and Prof. Benno Werlen. Chinese Geography Outstanding Achievement Awards were presented to Prof. Dadao Lu, Prof. Ke Liao and Prof. Cairui Jing. The representatives from the upcoming IGU Regional Conferences and congresses presented their programmes. Then the IGC flag was handed over to Prof. Ehmet Ertek, the representative of the Organizing Committee of the 34th International Geographical Congress. At last, Yukio Himiyama, the new President of IGU made a speech.

Apart from the congress itself, some key events were organized before the congress. On August 16-21, 292 teachers and students from 47 countries and regions in the world participated in the 13th International Geography Olympiad, which included written tests, multimedia quizzes and field work tests. Meanwhile, several pre-conferences under IGU Commissions on GIS, Geographical Education, Urban Challenges in a Complex World, Geography of Tourism, Leisure and Global Change, Political Geography, Health and Environment and Sustainability of Rural Systems were held in various cities of China ahead of the congress. On August 18-20, IGU Executive Committee Meeting was convened in Tianjin.

\section{(ZHANG Guoyou, ZHANG Xuanzi, ZHAO Xin, YU Xinfang)}

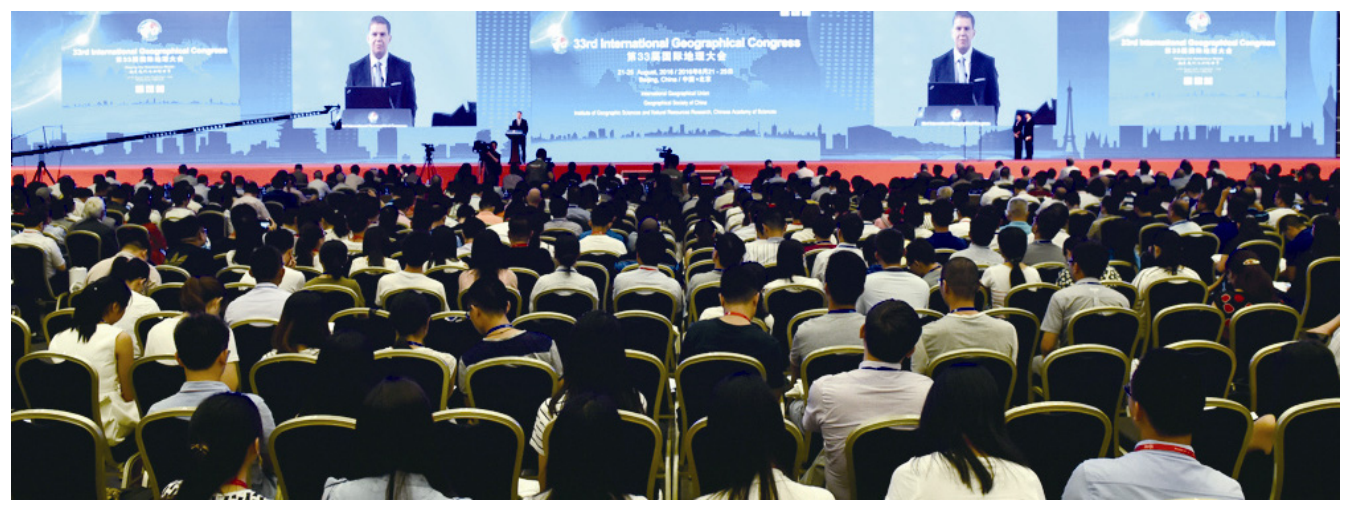

